\title{
Reproductive Toxicity to Male Mice of Nose Only Exposure to Water- Pipe Smoke
}

\author{
Badreldin H. Alia Sirin A. Adham ${ }^{b}$ Khalid A. Al Balushi ${ }^{a}$ Asem Shalabyc \\ Mostafa I. Waly ${ }^{d}$ Priyadarsin Manoja Sumaya Beegame Priya Yuvarajue \\ Abderrahim Nemmare \\ Departments of Pharmacology a and Pathologyc, College of Medicine and Health Sciences, and \\ Department of Food Science and Nutrition ${ }^{\mathrm{d}}$, College of Agricultural and Marine Sciences; and \\ Department of Biology ${ }^{b}$, College of Science; Sultan Qaboos University, Al Khod, Oman; and \\ eDepartment of Physiology, College of Medicine and Health Sciences, \\ United Arab Emirates University, Al Ain, UAE
}

\section{Key Words}

Water-pipe smoking $\bullet$ Mice $・$ Tobacco $\bullet$ Testes $・$ Reproductive hormones

\begin{abstract}
Background/Aims: Water-pipe smoking (WPS) is popular in the Middle East and is starting to gain popularity in several Western countries as well. It is widely and erroneously perceived to be less harmful than other forms of tobacco use. The reproductive adverse effects of cigarette smoking have been studied before with conflicting results, but data on the possible adverse reproductive effects of WPS are lacking. Here, we assessed the effects of nose-only exposure to mainstream WPS generated by commercially available honey-flavored "moasel" tobacco in mice. Methods: The duration of the session was $30 \mathrm{~min} /$ day for one month. Control mice were exposed to air. Twenty- four $h$ after the last exposure, mice were killed and the testes and plasma removed for analysis. In testicular homogenates total protein, alkaline phosphatase activity, several indices of oxidative damage and Vascular Endothelial Growth Factor Receptor 2 (VEGFR2) were quantified. The plasma concentrations of leptin, testosterone, estrogen and luteinizing hormone (LH) were also measured. Histological analysis of testes and lungs was also conducted. Results: WPS caused statistically significant decreases in the plasma concentrations of leptin, testosterone, and $\mathrm{LH}$, and in the concentrations of total protein and the antioxidant indices measured. A statistically non - significant decrease in VEGFR2 protein in the WPS exposed mice compared to the control mice was also found. The body and testicular weights of mice exposed to WPS, as well as their testicular alkaline phosphatase activity and light microscopic histology, and plasma estrogen concentration were all not significantly affected by WPS. Conclusion: Further studies on the functional implications of these findings in mice exposed to WPS for longer durations are warranted.
\end{abstract}

Badreldin H. Ali

KARGER 125
Department of Pharmacology and Clinical Pharmacy, College of Medicine and Health Sciences, Sultan Qaboos University, P. O. Box 35 Al Khod, Postal code 123 (Oman) E-Mail akthmali@squ.edu.om and E-Mail alibadreldin@hotmail.com 


\section{Introduction}

The popularity of water pipe smoking (WPS) has tremendously increased globally during the last few years [1-3]. According to Maziak et al. [4], WPS nomenclature is region - specific and includes names such as "hooka" (Africa and Indian subcontinent); "narghile" (Israel, Jordan, Lebanon, Syria); "Shisha”, "boory" or "goza” (Egypt, Saudi Arabia) and "Hubble bubble" (many regions). This centuries - old practice has recently sprung up rapidly around bars in college campuses the United States and Europe [5]. Although the pulmonary and extra -pulmonary adverse effects of cigarette smoking are well documented [6-10], much less has been reported on WPS, and there is a general (and erroneous) perception among users that WPS is relatively free from the adverse effects of cigarette smoking $[5,11,12]$.

Although research on the effects of cigarette smoking on male fertility has yielded some contradictory results, most of the reported studies seem to suggest that it can adversely influence the reproductive function in both laboratory animals [13-15] and humans $[16,17]$. However, as far as we are aware, there are no reports in the literature on the possible effects of WPS on male reproduction in humans or laboratory animals. Therefore, we thought it of interest to study some morphological, histological, biochemical and molecular aspects of WPS in a mouse model. In the molecular aspects of the study, vascular endothelial growth factor receptor 2 (VEGFR2) and its receptors expression has been detected not only in the endothelial cells but also on the non-endothelial cells particularly on the Leydig cells of the mice testis, it has been suggested that over expression of vascular endothelial growth factor (VEGF) might be involved in regulating male mice fertility, and that high concentrations of VEGF was reported in semen [18]. Since it was established that VEGFA acts as a putative paracrine regulator in seasonally controlled spermatogenesis, and it is a necessary cytokine for the microcirculation in the testis of seasonally reproduced ruminants [19], we aimed here to measure the levels of its main angiogenic receptor VEGFR2 in mice testis exposed to WPS.

\section{Materials and Methods}

\section{Animals}

BALB/ c mice (Taconic Farms Inc. Germantown, NY, USA) were kept in the College of Medicine and Health Sciences animal house (United Arab Emirates University, UAEU) on a 12-hour light-dark cycle. The animals $(n=24)$ were placed in cages and supplied with nutritionally-adequate pelleted food and water ad libitum. All the experiments were performed in accordance with the protocols approved by the Institutional Animal Care and Research Advisory Committee as described previously [8, 9, 20, 21]. After the animals were acclimatized for one week, they were divided at random into two groups: control ( $\mathrm{n}=12)$ and WPS-exposed group $(\mathrm{n}=12)$. The animals were placed in soft restraints and connected to the exposure tower $[8,9,20$, 21], and were exposed to WPS or air through their noses using a nose-only exposure system (InExpose System, Scireq, Canada). Mice were exposed to mainstream WPS generated by commercially available honey flavored "moasel" tobacco (Al Fakher, Ajman, UAE). The tobacco was lit with instant light charcoal disk (Star, $3.5 \mathrm{~cm}$ diameter and $1 \mathrm{~cm}$ width). A standard of one puff of 2-s duration was inhaled once a minute, followed by $58 \mathrm{~s}$ of fresh air applied at a rate of $6 \mathrm{ml} / \mathrm{s}$. The duration of the session was $30 \mathrm{~min} /$ day for one month. The control mice were similarly treated and were exposed to filtered air for the same duration.

Blood collection and tissue homogenization

After the given time of exposure to air or WPS, the animals were weighed and then anesthetized intraperitoneally with pentobarbital sodium ( $45 \mathrm{mg} / \mathrm{kg}$ ), and blood (about $1.5 \mathrm{ml}$ ) was then collected from the inferior vena cava in EDTA (4\%) and centrifuged at $900 \mathrm{~g}$ for $15 \mathrm{~min}$ at $4^{\circ} \mathrm{C}$. The plasma samples obtained were stored at $-80^{\circ} \mathrm{C}$ to await biochemical analysis. Then the lung and testes from all mice were collected and rinsed with ice-cold PBS (pH 7.4). The testes were weighed and the right testis and the upper half of the left testis immediately frozen at $-80^{\circ} \mathrm{C}$ pending biochemical and molecular studies. Half the left testis was 
homogenized in $0.1 \mathrm{M}$ phosphate buffer pH 7.4 containing $0.15 \mathrm{M} \mathrm{KCl}, 0.1 \mathrm{mM}$ EDTA, $1 \mathrm{mM}$ DTT and $0.1 \mathrm{mM}$ phenylmethylsulfonylfluoride at $4^{\circ} \mathrm{C}$. The homogenates were centrifuged at $4^{\circ} \mathrm{C}$ for 10 minutes at $3000 \mathrm{~g}$ to remove cellular debris and supernatants were used for further analysis. The right testis was deep frozen at $-80^{\circ} \mathrm{C}$ and used subsequently in certain molecular tests (see below).

\section{Biochemical methods}

Plasma analysis. The concentrations of testosterone, luetinizing hormone and estrogen in plasma were measured by ELISA methods as described before [22]. Lepin concentration was measured by an ELISA method using a kit from R\& D systems (Minneapolis, MN, USA). Alkaline phosphatase activity was measured spectrophotometrically using a commercial kit (Human, Weisebaden, Germany).

Testicular homogenate analysis. Testicular Protein content was measured by Bradford's method as described before $[8,9]$. The indices of the anti-oxidant capacity [superoxide dismutase (SOD) and catalase activities, and the concentrations of reduced glutathione (GSH) and total anti-oxidant capacity (TAC) ] were measured in the testicular tissues using ELISA kits. The concentration of ascorbic acid (AA) was measured by an HPLC method described by Levine et al [23]. The activity of alkaline phosphatase was measured spectrophotometrically using a commercial kit.

Histological methods. The lung tissue was placed in $10 \%$ formalin to await subsequent routine light microscopic histological processing [24], together with the lower part of the left testis which was placed first in Bouin's fluid for an hour [25], and then transferred to $10 \%$ formalin.

Molecular methods. Total protein isolation from mice testis and western blotting for VEGFR2: Mice testes from the twelve different mice were homogenized by crushing $0.5 \mu \mathrm{g}$ of each using a micro size mortar and pistol in cold lysis buffer (Cell Signaling Technologies, USA) containing protease inhibitor cocktail (Sigma Aldrich, USA). Testicular lysates were centrifuged and quantified using BCA protein assay system (Pierece, USA). Aliquots of total protein of each sample $(100 \mu g s)$ were loaded into a 15\% SDS-PAGE gel. Protein was transferred to PVDF membrane (Millipore, Belgium). The membranes were blocked with 5\% nonfat milk in TBST (10 mM Tris, pH 7.5, $150 \mathrm{mM} \mathrm{NaCl}, 0.05 \%$ Tween 20) and probed with 1:1000 dilution of VEGFR2 primary monoclonal rabbit antibody (Cell Signaling technology, USA) in 5\% nonfat milk/TBST. Immunoblots were then processed with horseradish-peroxidase-conjugated anti-rabbit immunoglobulin G (IgG) using the enhanced BM Chemiluminescence Western Blotting Kit (Mouse/Rabbit) (Roche, USA). The membranes were cut off according to the molecular weight prestained protein marker blotted using beta Actin primary antibody. The blots were exposed to X-ray film (Roche, U.S.A) at room temperature. Densitometry was carried out on the scanned X-ray film using Image J software which measures the relative intensity of the test band in respect to the loading control Actin. Immunofluorescent staining: The testis were processed and embedded in paraffin blocks. Cross sections of $6 \mu \mathrm{M}$ were placed on positively charged slides. The sections were deparaffinized in xylene, rehydrated in a series of ethanol (100\%, 95\% and 75\%) and tap water, then antigen retrieval was performed using $1 \mathrm{mM}$ Ethylenediaminetetraacetic acid (EDTA) (pH 9.0), in $95^{\circ} \mathrm{C}$ water bath for $30-40 \mathrm{~min}$. The activity of endogenous peroxidases was blocked by $2 \%$ hydrogen peroxide for $15 \mathrm{~min}$. The slides were washed twice in phosphate buffer saline (PBS) then in PBS + 0.05\% Triton X-100 for 5 min each. They were incubated with a blocking solution of $5 \%$ normal goat serum for 30 $\mathrm{min}$ at room temperature, then incubated overnight at $4^{\circ} \mathrm{C}$ with VEGFR2 primary antibody (cell signaling technology USA). The sections were washed three times in PBS (5 minutes/wash) and then incubated for 30 minutes at room temperature with Alexa Fluor ${ }^{\circledR}$ 647-conjugated anti-rabbit secondary antibodies (1:500) (Cell Signaling Technology, USA). The sections were washed three times in PBS (5 minutes/wash), followed by staining with 4',6-diamidino-2-phenylindole (DAPI) nuclear stain solution (25: $1000 \mathrm{v} / \mathrm{v}$ ) for three minutes. The cells were washed gently three times in PBS (5 minutes/wash), mounted using fluorescent mounting medium (Dako, USA), coversliped, examined and photographed with a fluorescence microscope Olympus B5X under 400X.

Drugs, chemicals and kits

Alkaline phosphatase kit was bought from Human mbH, Wiesbaden, Germany, and kits for TAC, catalase, GSH and SOD were all purchased from Biovision Incorporated, Milpitas, CA, USA. The hormones testosterone, LH and estrogen were from DRG Instruments Gmbh, Marburg Germany. All other chemicals used were of the highest grade commercially available.

\section{KARGER}



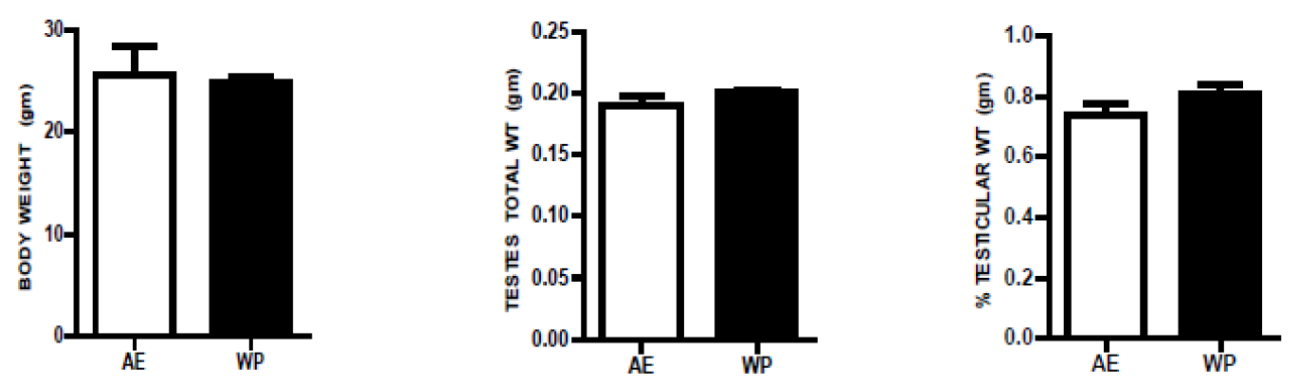

Fig. 1. Final body and testicular weights in control mice (open columns), and mice exposed to WPS for 30 min/day for one month (filled columns). Each column and vertical bar represents mean + SEM (from 12 mice in each group). No statistically significant differences between the two groups were found.

Fig. 2. The concentrations of testosterone and luteinizing hormone (LH) in control mice (open columns), and mice exposed to WPS for $30 \mathrm{~min} /$ day for one month (filled columns). Each column and vertical bar represents mean + SEM (from 12 mice in each group). The hormones levels were statistically significantly lower in treated mice when compared with the control $(\mathrm{P}<0.05)$.
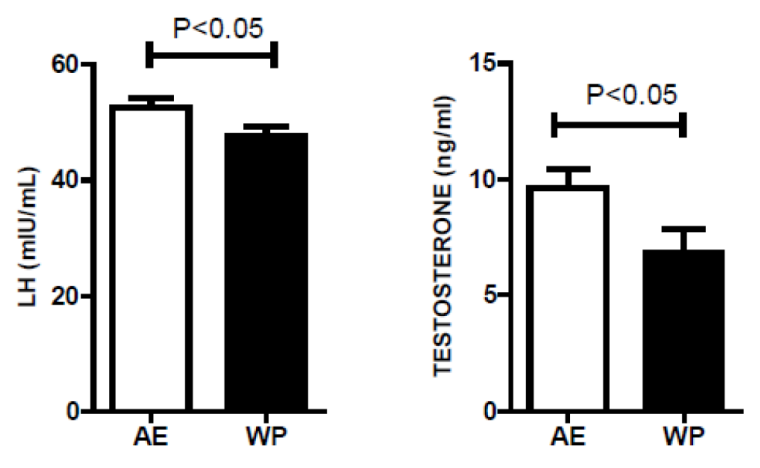

\section{Statistical analysis}

Values were calculated as mean \pm S.E.M. (number of mice used). Statistical significance of the data was assessed using Students' t test and p values $<0.05$ were considered significant.

\section{Results}

The one - month exposure to WPS caused no significant change in the body or testicular weight of mice (Fig. 1).

As shown in Fig. 2, the plasma concentrations of testosterone and LH were significantly decreased in mice exposed to WPS, compared to those that were exposed to normal air (P $<0.05$ ). The plasma concentration of estrogen was, however, unaffected by the treatment (data not shown).

The one - month exposure to WPS induced significant $(\mathrm{P}<0.05)$ reductions in the testicular concentrations and activities of several indices of oxidative stress that include GSH, TAC, catalase and SOD, as well as the concentration of total protein (Fig. 3).

As shown in Fig. 4, the plasma concentration of leptin was significantly decreased WPS $(\mathrm{P}<0.05)$. The activity of alkaline phosphatase in testicular homogenate was not significantly affected by the treatment $(\mathrm{P}>0.1)$.

Fig. 5 depicts the histology and the testes and lungs in mice exposed to WPS or air. Compared with the air-exposed group (A), lung sections obtained from mice exposed for one month to WPS showed the presence of interstitial infiltration of inflammatory cells, including neutrophils and lymphocytes (B). The light microscopic analysis of the light microscopic histological structure of seminiferous tubules in the two groups of mice ( $C$ and D) demonstrated no clear differences. In both groups there were spermatogonia, spermatocytes and spermatids. 
Fig. 3. The concentrations of and activities of several antioxidant indices in testicular homogenates in control mice (open columns), and mice exposed to WPS for $30 \mathrm{~min} /$ day for one month (filled columns). Each column and vertical bar represents mean + SEM (from 6 -7 mice in each group). All the antioxidant indices were statistically significantly lower in treated mice when compared with the control $(\mathrm{P}<0.05)$.

Western blot analysis showed that there were a slight decrease in the levels of VEGFR2 after the one month exposure to WPS. The decrease was not statistically significant. Parallel results were obtained from the immunofluorescence staining of the testis with no obvious decrease in the distribution of VEGFR2 in the studied sections (Fig. 6 and $7)$.

\section{Discussion}

In this study, exposure of mice to WPS for one month caused significant reductions in the protective antioxidant indices in the testes, and reduced the plasma concentrations of testosterone and LH. However this was not accompanied by any significant change in the body or testicular weight or histology or in the VEGFR2. This suggests that the exposure of male mice to WPS for one month (which causes several adverse effects in the respiratory and cardiovascular systems [20, 21]) also produced some adverse actions in the reproductive system of these rats. The exposure of mice to WPS was for only one month. It is conceivable that exposure to WPS for longer durations might cause more damage to the reproductive (and other) organs of the animals, and if this can be confirmed in humans, it would be a serious
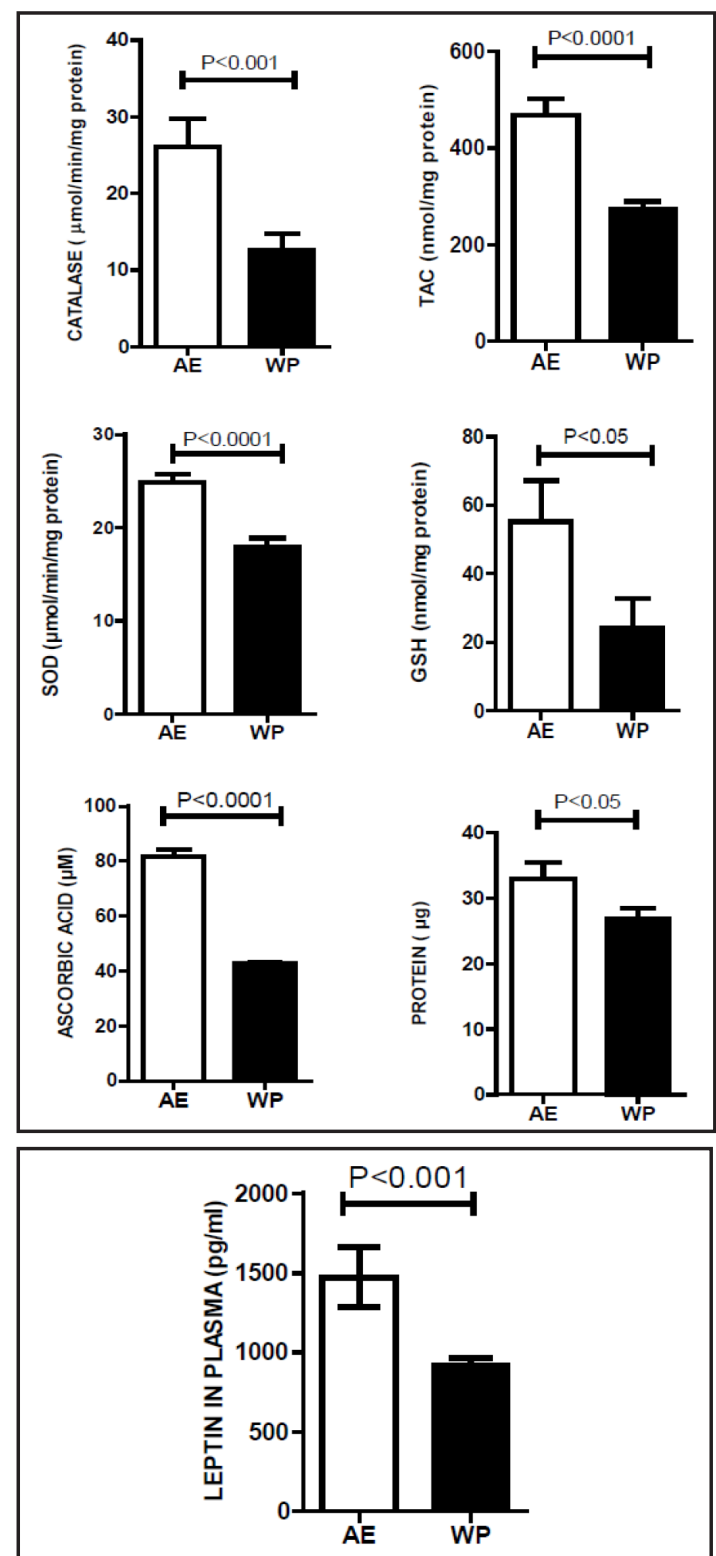

Fig. 4. The concentration of leptin in plasma, and the activity of alkaline phosphatase in testicular homogenates in control mice (open columns), and mice exposed to WPS for $30 \mathrm{~min} /$ day for one month (filled columns). Each column and vertical bar represents mean + SEM (from 6-7 mice in each group).

public health concern.

In this study, we tested the effect of WPS on the oxidant system in the testicular homogenates. It is established that enzymatic and non -enzymatic anti-oxidants, produced within the cells function to stop the regeneration of reactive oxygen species (ROS) in the oxidation of fats [26] and both inhibition and activation of proteins [27]. The activities of the antioxidant enzymes (e.g. CAT, and SOD) and non -enzymatic antioxidant (e.g. GSH) within the testicular tissue were found to be significantly reduced in the WPS -exposed group as compared to the antioxidants in the control group. These antioxidants are known to take part in the recycling of the harmful actions of free radicals and free forms of oxygen [28], 
Fig. 5. Photo-micrograph of a representative of (A) lung tissue from a control mouse (exposed to air only) showing normal structure and lung tissue from a mouse exposed to water pipe smoking (WPS) for $30 \mathrm{~min} /$ day for one month (B), showing interstitial inflammation and congestion (arrow) and inflammatory cells around terminal bronchiole (arrow head). Photomicrographs of testicular tissue from a control mouse (C) and a mouse exposed to WPS as above (D) both showed seminiferous tubules with normal spermatogenesis. (200 X magnification for lung tissues and 400 $\mathrm{X}$ for testicular tissues).

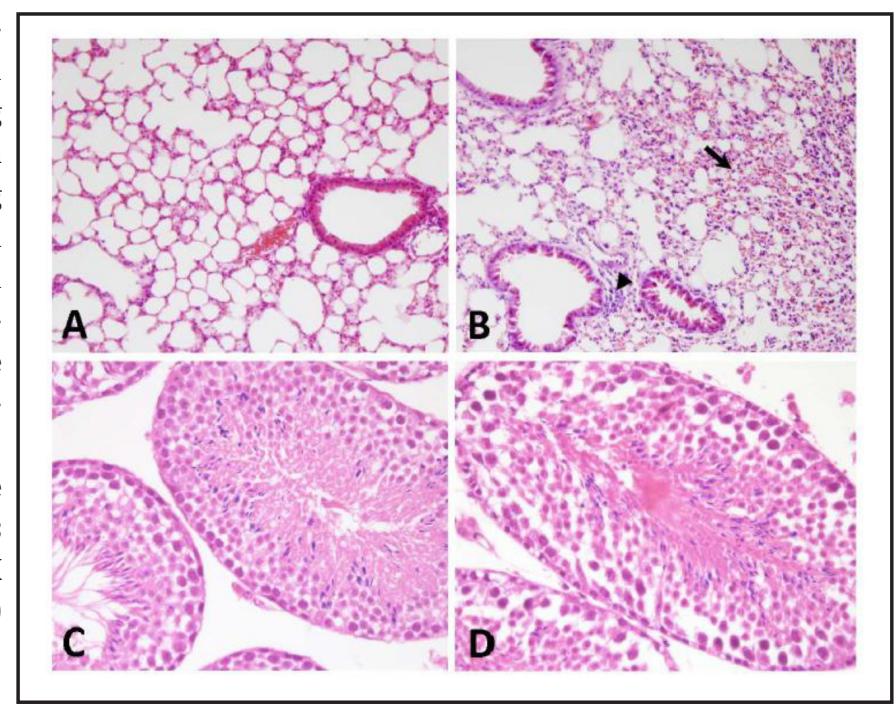

Fig. 6. Western blot showing the levels of total VEGFR2 expressed in the control (open columns) and WPS - exposed mice (filled columns). The graph represents the average densitometry quantification of the VEGFR2 signals obtained from two independent experiments, the error bars represent \pm standard deviation in control mice (open columns), and mice exposed to WPS for $30 \mathrm{~min} /$ day for one month (filled columns).

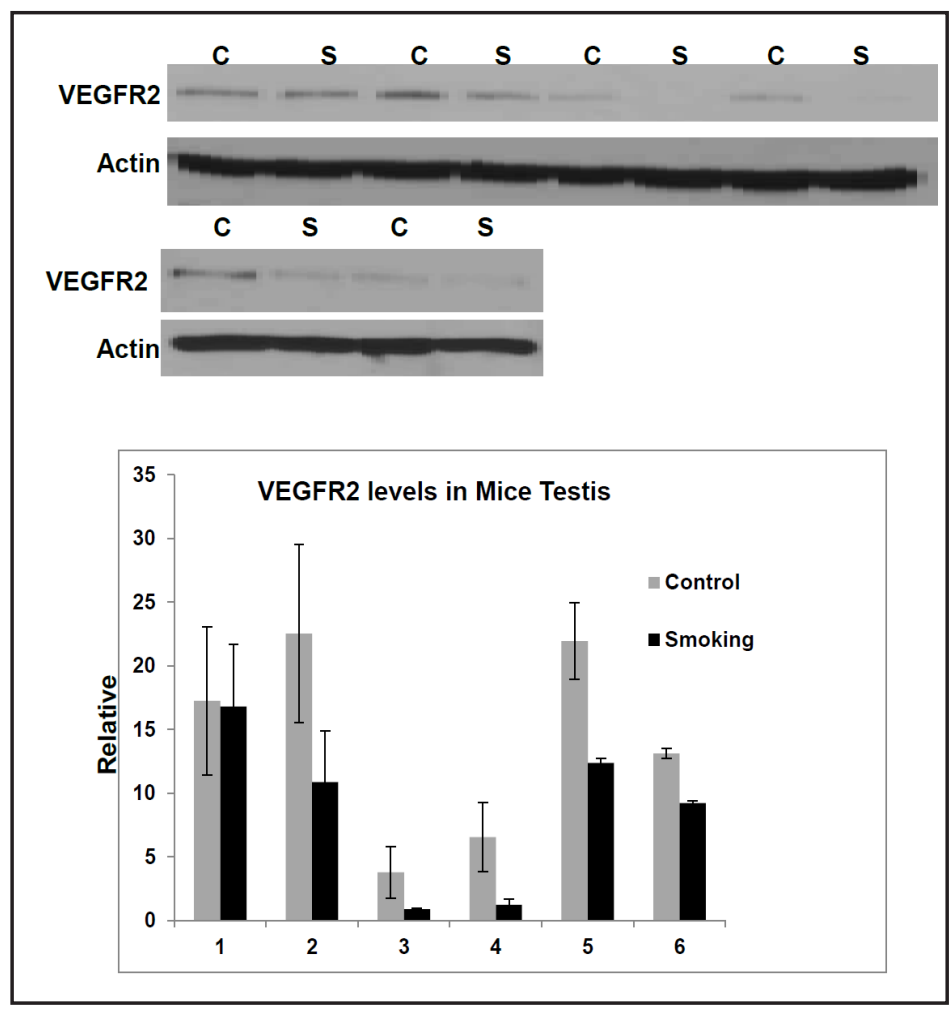

and their reduction in testicular tissues of mice exposed to a relatively short duration of WPS suggests that these testes would be susceptible to the adverse and may be toxic actions of WPS and other xenobiotics, resulting in impaired cell function and cell death. Recently oral administration of nicotine $(0.5$ and $1 \mathrm{mg} / \mathrm{kg})$ to rats for 30 days has been reported to significantly decrease several indices of antioxidant profile in plasma [29, 30]. It is not known whether the significant decreases that we have found in testicular tissues of mice exposed to WPS for 30 days could be ascribed solely to nicotine, or / and to other components in the WPS, and this warrants further studies.

It has been reported that VEGFA and its main angiogenic receptor VEGFR2 (KDR) play an important role in the maintenance of microcirculation in ruminants testis as a vital 


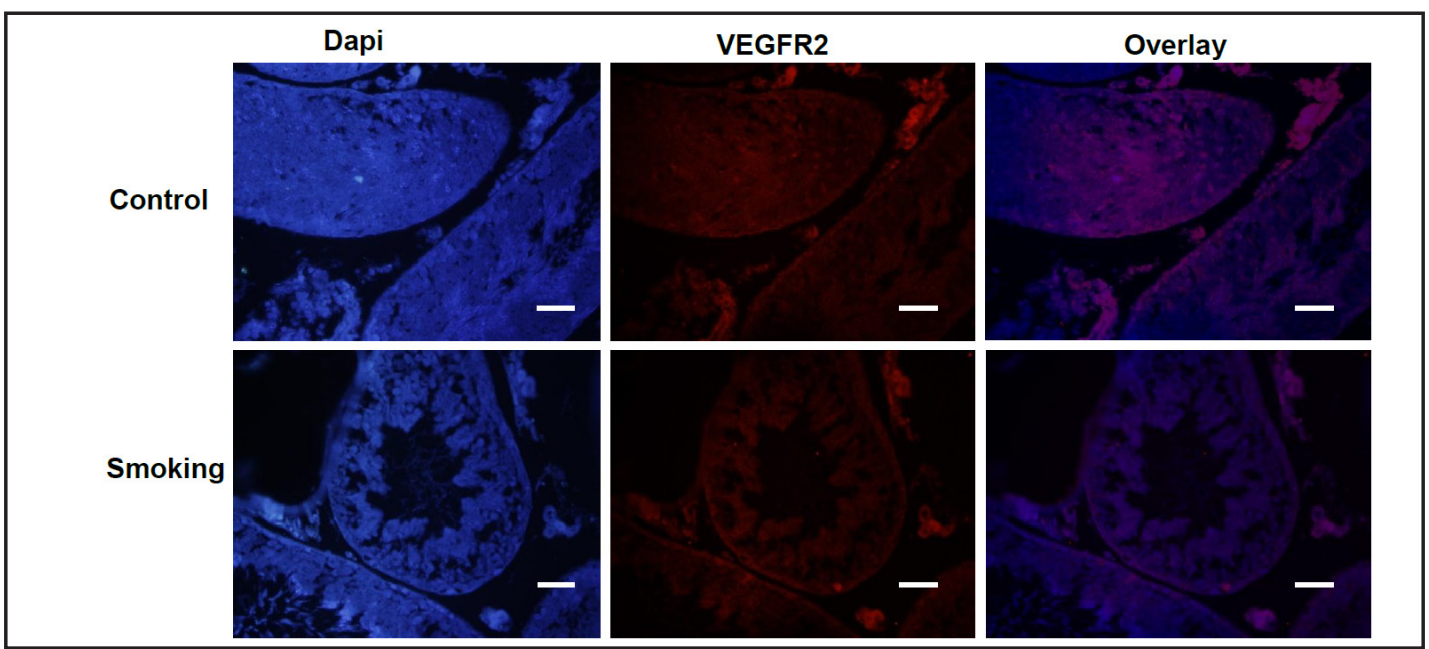

Fig. 7. Immunofluorescence staining of testes of control and WPS- exposed mice of shows VEGFR2 localization in the mice spermatocytes.The size of the scale bar is equal to 50 micrometer. There was no clear difference between the control and WPS treated mice.

local regulatory determinant of testicular functions [19]. Although our results showed a slight decrease in the expressed VEGFR2 in WPS treated groups compared to the control in western blot that decrease was not significant. This might be more obvious if the number of our samples was higher, and / or the duration of exposure was for a longer period of time. A reduced expression of testicular VEGFR2 implies that WPS has a negative effect on the microcirculation of the mice testis which might reduce the fertility of these animals.

As far as we are aware, there are no reports in the literature on the effect of WPS on reproductive hormones. In this work, a small but statistically significant decreases in plasma testosterone and LH concentrations were found in mice exposed to WPS, confirming previous research in humans that reported adverse effects of cigarette smoking on female reproduction [31], and on the concentrations of testosterone and other steroidal hormones in adult men [32,33], and rats [15]. However, the lack of effect of WPS smoking in this work on plasma estrogen concentration was different from the report of Barrett -Connor and Khaw [34] which suggested that cigarette smoking increased endogenous estrogen levels in humans. In the latter report, cigarette smoking was for a much longer period than in this work, and this may explain some of this discrepancy.

In this work WPS significantly reduced the plasma concentration of the adipocyte-derived hormone leptin. Leptin plays a vital role as a metabolic cue for the reproductive system, and low leptin levels are associated with decreased fertility in both males and females subjects [35]. In this work, WPS induced a significant decrease in leptin plasma concentration, an action that goes in line with the decreased testosterone and LH levels in plasma and the significant decreases in the antioxidant indices in testicular homogenates. However, there are no clear association between this reduced leptin level and body weight, as expected. Further studies on the possible mechanism(s) for the increased leptin in plasma following WPS are warranted. It has been shown before that cigarette smoking reduces plasma leptin concentration in humans, probably via increased levels of plasma catecholamines [36]. In sharp contrast, others have shown that nicotine in smoking actually increases plasma leptin levels [37].

As was reported before [20] sections of lung from air-exposed mice in this work had a normal appearance unlike the lung sections obtained from mice exposed for one month to WPS which showed the presence of interstitial infiltration of inflammatory cells, including neutrophils and lymphocytes. No noticeable gross or histological changes in the testes of mice exposed to WPS for 30 days was observed. This was despite the fact that the same dose produced a small but significant reduction in the plasma concentrations of testosterone and 
LH. One possible explanation for this finding was that the degree of insult by WPS to this organ was not sufficient to produce light microscopic changes, but this does not rule out the possibility that a longer duration of exposure to WPS, and /or further examination of the testicular ultrastructure by electron microscopy might elicit some histopathological changes in the testes. Electron microscopy study was not feasible for us in this work, but might be worth while conducting in future experiments.

In conclusion, exposure of mice to WPS for 30 days caused some adverse effects on the antioxidant indices in testes and on plasma testosterone and LH concentrations. Further studies on the effect of WPS for longer durations, and identification of the components in WPS responsible for the adverse effects are warranted.

\section{Acknowledgments}

This work was supported by Sultan Qaboos University (in Oman) and the United Arab Emirate University (in the United Arab Emirates). Thanks are due to Ms. H. Al Issaei for her technical help.

\section{References}

1 Alvur MT, Cinar N, Akduran F, Dede C: Fallacies about Water Pipe Use in Turkish University Students What Might Be the Consequences? Asian Pac J Cancer Prev 2014;15:1977-1980.

-2 Aslam HM, Saleem S, German S, Qureshi WA: Harmful effects of shisha: literature review. Int Arch Med 2014;7:16.

3 Maziak W: The global epidemic of waterpipe smoking. Addict Behav 2011;36:1-5.

4 Maziak W, Ward KD, Afifi Soweid RA, Eissenberg T: Tobacco smoking using a waterpipe: a re-emerging strain in a global epidemic. Tob Control 2004;13:327-333.

-5 Martinasek MP, McDermott RJ, Bryant CA: Antecedents of university students' hookah smoking intention. Am J Health Behav 2013;37:599-609.

6 Dorey G: Is smoking a cause of erectile dysfunction? A literature review. Br J Nurs 2001;10:455-465.

7 Levin L, Kessler-Baruch 0: Cigarette smoking and the alveolar bone around teeth and dental implants. NY State Dent J 2013;79:53-59.

-8 Nemmar A, Raza H, Subramaniyan D, John A, Elwasila M, Ali BH, Adeghate E: Evaluation of the pulmonary effects of short-term nose-only cigarette smoke exposure in mice. Exp Biol Med (Maywood) 2012;237:1449-1456.

-9 Nemmar A, Raza H, Subramaniyan D, Yasin J, John A, Ali BH, Kazzam EE: Short-term systemic effects of nose-only cigarette smoke exposure in mice: role of oxidative stress. Cell Physiol Biochem 2013;31:15-24.

$>10$ Unverdorben M, Mostert A, Munjal S, van der Bijl A, Potgieter L, Venter C, Liang Q, Meyer B, Roethig HJ: Acute effects of cigarette smoking on pulmonary function. Regul Toxicol Pharmacol 2010;57:241-246.

-11 Martinasek MP, McDermott RJ, Martini L: Waterpipe (hookah) tobacco smoking among youth. Curr Probl Pediatr Adolesc Health Care 2011;41:34-57.

12 Martinasek MP, Gibson-Young L, Forrest J: Hookah smoking and harm perception among asthmatic adolescents: findings from the Florida youth tobacco survey. J Sch Health 2014;84:334-341.

13 Ahmadnia H, Ghanbari M, Moradi MR, Khaje-Dalouee M: Effect of cigarette smoke on spermatogenesis in rats. Urol J 2007;4:159-163.

14 Stillman RJ, Rosenberg MJ, Sachs BP: Smoking and reproduction. Fertil Steril 1986;46:545-566.

15 Oyeyipo IP, Raji Y, Bolarinwa AF. Nicotine alters male reproductive hormones in male albino rats: The role of cessation. J Hum Reprod Sci 2013;6:40-44.

-16 Abbott LC, Winzer-Serhan UH: Smoking during pregnancy: lessons learned from epidemiological studies and experimental studies using animal models. Crit Rev Toxicol 2012;42:279-303. 
Ali et al.: Effect of Water - Pipe Smoking on Rat Testes

17 Yu B, Chen J, Liu D, Zhou H, Xiao W, Xia X, Huang Z: Cigarette smoking is associated with human semen quality in synergy with functional NRF2 polymorphisms. Biol Reprod 2013;89:5:1-7.

18 Korpelainen EI1, Karkkainen MJ, Tenhunen A, Lakso M, Rauvala H, Vierula M, Parvinen M, Alitalo K: Overexpression of VEGF in testis and epididymis causes infertility in transgenic mice: evidence for nonendothelial targets for VEGF. J Cell Biol 1998;143:1705-1712.

19 Schön J, Blottner S, Gabler C, Fickel J: Vascular endothelial growth factor A is a putative paracrine regulator in seasonally controlled spermatogenesis: insights from a ruminant model, the roe deer. Growth Factors 2010;3:202-210.

-20 Nemmar A, Raza H, Yuvaraju P, Beegam S, John A, Yasin J, Hameed RS, Adeghate E, Ali BH: Nose-only waterpipe smoking effects on airway resistance, inflammation, and oxidative stress in mice. J Appl Physiol 2013;115:1316-1323.

21 Nemmar A, Yuvaraju P, Beegam S, John A, Raza H, Ali BH: Cardiovascular effects of nose-only water-pipe smoking exposure in mice. Am J Physiol Heart Circ Physiol 2013;305:H740-746.

22 Ali BH, Al-Lawati I, Beegam S, Ziada A, Al Salam S, Nemmar A, Blunden G: Effect of Hibiscus sabdariffa and its anthocyanins on some reproductive aspects in rats. Nat Prod Commun 2012;7:41-44.

23 Levine M, Wang Y, Rumsey SC: Analysis of ascorbic acid and dehydroascorbic acid in biological samples. Methods Enzymol 1999;299:65-76.

24 Culling CFA, Allison RT, Barr WT: Cellular Pathology Technique. 4th ed. London: Butterworth-Heinemann, 1985.

25 Dutta D, Park I, Mills NC: Fixation temperature affects DNA integrity in the testis as measured by the TUNEL assay. Toxicol Pathol 2012;40:667-674.

-26 Jahan S, Zahra A, Irum U, Iftikhar N, Ullah H: Protective effects of different antioxidants against cadmium induced oxidative damage in rat testis and prostate tissues. Syst Biol Reprod Med 2014;199-205.

-27 Nathan C, Cunningham-Bussel A: Beyond oxidative stress: an immunologist's guide to reactive oxygen species. Nat Rev Immunol 2013;13:349-361.

28 Noblanc A, Kocer A, Chabory E, Vernet P, Saez F, Cadet R, Conrad M, Drevet JR: Glutathione peroxidases at work on epididymal spermatozoa: an example of the dual effect of reactive oxygen species on mammalian male fertilizing ability. J Androl 2011;32:641-650.

29 Oyeyipo IP, Raji Y, Bolarinwa AF: Antioxidant profile changes in reproductive tissues of rats treated with nicotine. J Hum Reprod Sci 2014;7:41-46.

-30 Oyeyipo IP, Raji Y, Bolarinwa AF: Nicotine alters serum antioxidant profile in male albino rats. N Am J Med Sci 2014;6:168-171.

31 Talbot P, Lin S: The effect of cigarette smoke on fertilization and pre-implantation development: assessment using animal models, clinical data, and stem cells. Biol Res 2011;44:189-194.

-32 Field AE, Colditz GA, Willett WC, Longcope C, McKinlay JB: The relation of smoking, age, relative weight, and dietary intake to serum adrenal steroids, sex hormones, and sex hormone-binding globulin in middleaged men. J Clin Endocrinol Metab 1994;79:1310-1316.

-33 Jeng HA, Chen YL, Kantaria KN: Association of cigarette smoking with reproductive hormone levels and semen quality in healthy adult men in Taiwan. J Environ Sci Health A Tox Hazard Subst Environ Eng 2014;49:262-268.

34 Barrett-Connor E, Khaw KT: Cigarette smoking and increased endogenous estrogen levels in men. Am J Epidemiol 1987;126:1871-1892.

-35 Ratra DV, Elias CF: Chemical identity of hypothalamic neurons engaged by leptin in reproductive control. J Chem Neuroanat 2014;pii: S0891-0618(14)00041-6.

-36 Reseland JE, Mundal HH, Hollung K, Haugen F, Zahid N, Anderssen SA, Drevon CA: Cigarette smoking may reduce plasma leptin concentration via catecholamines. Prostaglandins Leukot Essent Fatty Acids 2005;73:43-49.

-37 Eliasson B, Smith U: Leptin levels in smokers and long-term users of nicotine gum. Eur J Clin Invest 1999;29:145-152. 